\title{
Aging Trends and Impact on Dental Practice
}

\author{
${ }^{1}$ Amir Catic, ${ }^{2}$ Adnan Catovic, ${ }^{2}$ Dragutin Komar \\ ${ }^{1}$ Assistant Professor, Department of Prosthodontics, School of Dental Medicine, University of Zagreb, Hrvatska, Croatia \\ ${ }^{2}$ Professor, Department of Prosthodontics, School of Dental Medicine, University of Zagreb, Hrvatska, Croatia
}

Correspondence: Amir Catic, Assistant Professor, Department of Prosthodontics, School of Dental Medicine, University of Zagreb, Hrvatska, Croatia, e-mail: catic@sfzg.hr

\section{ABSTRACT}

Aging is a process that takes place in every living individual. Every 10th person of the world population is 60 years old or above. Chronic diseases, low income and social status of the elderly, together with physiological changes caused by aging, affect the condition of the stomatognathic system. In the present article many studies are demonstrated considering tooth loss, state of the stomatognathic system and dental appliances as well as different organ changes in elderly through the years in different countries. The team approach of medical and dental experts in treating elderly patients is emphasized as well as different dental treatment options depending on general health factors.

Keywords: Gerodontology, Elderly, Tooth loss, Prosthodontics.

\section{INTRODUCTION}

The physiological processes that take place from conception to death are continuous and do not occur stepwise; development merges gradually into maturation and ultimately aging. ${ }^{1}$ According to the UN, in 2002, 629 million people, or every 10th person of the world population, were aged 60 years or above. ${ }^{2}$ WHO data for 2001 indicated that a healthy male aged 65 could expect to live 16 years more, and a healthy woman another 20 years. $^{3}$ One-third of the elderly aged eighty-five years or more use healthcare facilities or nursing homes. Chronic diseases, low income and social status of the elderly, together with physiological changes caused by aging, affect the condition of the stomatognathic system. Specific problems which distinguish gerodontological patients from others occur when their health disorders overlap and interfere with their dental care; consummation of numerous and different medications interferes with medications used in dentistry; or their physical frailty limiting their mobility and making health care facilities less accessible. ${ }^{4}$ Elderly patients face lack of motivation, often related to different problems, whether financial or psychological, because depression is more common condition in the aged. Other difficulties include adaptation to new prosthodontic appliances, compounded by communication difficulties resulting from preexisting permanent damage to sensory organs as part of the aging process. ${ }^{5}$ Gerodontology as an interdisciplinary science studies healthy stomatognathic system, but it also deals with curing and preventing illnesses in the same system. The most important thing is to introduce a team approach in which medical and dental experts work together in treating patients of this age group. ${ }^{4}$

\section{STOMATOGNATHIC SYSTEM AND AGING}

Before 1940s, it was considered that tooth loss and complete edentulism were inevitable consequences of aging. The introduction of preventive dentistry in the middle of the 20th century made people aware that they could reach their old age while still having their own teeth. The decline in the percentage of the edentulous adults had some experts asking if and when they should discontinue teaching the fabrication of complete dentures. However, studies showed that the need for fixed and removable prosthodontic appliances will grow in elderly populations. ${ }^{6}$ Similar investigation showed that the need for complete dentures will grow regardless of the fall in the percentage of younger edentulous adults. US National epidemiological research results show a $10 \%$ decrease in number of edentulous patients in every decade. ${ }^{7}$ In a multinational study, conducted between 1990 and 1994, the oral health status and treatment needs of 19,845 subjects in age groups 55 to 64,65 to 74 and $>74$ years from Austria, Byelorussia, Germany, Hungary, Italy, Poland, Slovenia and the Czech Republic were determined. The oral health status of the adult populations of all these countries was characterized by a high rate of tooth loss and edentulism. In Germany, Poland, the Czech Republic and Hungary, edentulism for the 55 to 64 years old varied from 17 to $20 \%$. In Byelorussia and Austria $10 \%$ of the subjects were edentulous, $6,7 \%$ in Slovenia, and $5,8 \%$ in Italy. In the age group of 65 to 74 years old edentulism increased even further; more than $1 / 3$ of all subjects in the Czech Republic, Germany and Poland had no teeth; in the Hungarian sample the proportion exceeded $50 \%$. Without significant differences the lowest edentulism was recorded in the Italian and Austrian samples. ${ }^{8}$ In north-east Germany, a study considering dental status in the oldest population was made. The results showed that $16 \%$ of the population between 60 and 65-year-old was edentulous, and in the population aged between 75 and 79 results showed $30 \% .{ }^{9}$ Marcus et al studied edentulism in New England in the 1990s and found that 36.7\% of 1156 examinees were toothless. The highest edentulous percentage was found in the oldest group age, $>85$-year-old in which $42 \%$ of women and $52 \%$ of men were complete 
edentate. ${ }^{10}$ In Denmark, a study of 16,690 subjects of all age groups was undertaken to evaluate the Danish dental health care system's level of achievement for the year 2000, compared to similar studies carried out in 1987 and 1994. In all, 8\% of interviewed persons were edentulous, while $80 \%$ had 20 or more natural teeth. At the age of 65 to 74 years, $27 \%$ were edentulous and $40 \%$ had 20 teeth or more; $58 \%$ wore removable dentures. Goals for better dental health by the year 2000 were achieved for 35 to 44-year-old, whereas the goal of more people with functional dentition at the age of 65 years or older was not achieved. ${ }^{11}$ Common opinion is that periodontal disease is the most frequent cause of tooth loss in elderly population, but, new studies showed that the cause for most tooth extractions was caries. ${ }^{12,13}$ Tooth loss was studied in 145 healthy subjects aged 65 years and older. Findings suggest that intake levels of calcium and vitamin D aimed at preventing osteoporosis have a beneficial effect on tooth retention in elderly. ${ }^{14}$ Elderly patients have a strong will to retain their natural teeth for as long as possible, which increases the need for manufacturing fixed prosthodontic appliances, bridges and crowns, for patients of that age group. ${ }^{15}$ In the global overall over 65-year-old population there is a large number of complete denture wearers in at least one jaw, while one-third is completely edentate. Despite the fact that using complete dentures for therapeutical purposes is usual in this age group, not every edentate person wears a denture. ${ }^{16}$ The research made on elderly population in New England also showed that onethird of the examinees wore their dentures while sleeping. Problems caused by wearing dentures or patient's dissatisfaction were detected in $18 \%$ of cases. ${ }^{10}$ The purpose of the study made on the group of 175 users of the nursing homes in the city of Zagreb was to evaluate the condition of prosthodontic appliances compared to chronic diseases and the degree of patient's mobility. In $82 \%$ of the examinees replacement of old fixed and removable prosthodontic appliances was necessary. The most common health problems included cardiovascular and locomotory system diseases. ${ }^{17}$ Epidemiological study was made on 350 users of the nursing homes in the city of Zagreb aged between 65 and 94 years. The purpose of this investigation was to determine the condition of teeth and prosthodontic appliances. The results showed unsatisfactory condition of the appliances and teeth. From the total number of examined patients $75 \%$ was edentulous. Of 264 edentulous persons, $50 \%$ did not wear dentures, $60 \%$ of the appliances were graded unsatisfactory and needed to be repaired or replaced. The need for conservative therapy, surgical intervention or prosthodontic oral rehabilitation was recorded in $85 \%$ of the patients. ${ }^{18}$ Similar study considering the type of missing teeth, condition of prosthodontic appliances and the need for new appliances was made by Croatian authors. Dental status and anamnesis data were taken from 120 users of the nursing homes in Zagreb. The teeth that were missing in most cases were the first lower molars, and the most persisting teeth were lower canines. In average, crowns were older and in worse condition than the bridges. Complete dentures in lower jaw were more stabile, but they had worse retention than those in upper jaw. More than $82 \%$ of the examinees had the need for prosthodontic appliance. ${ }^{19}$ Caloss et $\mathrm{al}^{20}$ investigated the effect of denture stability on bite force and muscular effort and their results indicated that denture instability probably prevents denture wearers from using the full potential of their jaw muscles, especially during unilateral biting and chewing, even with two implants supporting the mandibular dentures.

Edentulous patients have difficulties chewing hard food, even with dentures of good technical quality. Such persons adjust their diet to compensate for their difficulties in chewing. Harder and Coarser foods, such as fruits, vegetables and meats, which are typically major sources of vitamins, minerals and proteins, come to be regarded as either difficult or nearly impossible to chew. Consequently, a tendency to favor softer, more processed foods develops. However, these foods are typically fairly high in fat and cholesterol content and may also be lacking in vitamins and minerals. It is possible that edentulous patients with poor nutrition may be at greater risk for a variety of diseases. Individuals with low consumption of vitamin A are known to be at greater risk for various forms of cancer, heart disease and rheumatoid arthritis. Intake of less than recommended levels of vitamin $\mathrm{E}$ is also associated with various cancers, as well as both heart disease and Parkinson's disease. Vitamin C consumption below required levels can lead to reduced immune system function and greater risks of cardiovascular disease, myocardial infarction and hypertension. Even with new conventional dentures, which improve ease of chewing, dietary intake often remains unchanged. ${ }^{21,22}$ A study conducted on 54 denture wearers was done with an aim and use of the HEI (Healthy Eating Index) to find a connection between the quality of dentures, chewing ability and amount of nutrients introduced to the body by food and eating. The subjects were divided in three groups according to the quality of the dentures. The HEI index had low results regardless of the quality of dentures and the ability to chew. ${ }^{23}$ There are also characteristic changes to the periodontal area due to aging of the individual. Aging evolves a rougher and thicker gingival tissue and there are qualitative and quantitative changes of the collagen. The aged periodontal ligament shows a lower amount of fibroblasts and there are visible changes and irregularities in its composition which changes the quality of gingival tissue. Compared to the aging of the other tissues of the body the changes to the cement are relatively regular, although the aging thickens the cement five to ten times, apical more than cervical. The changes to the alveolar bone due to aging are identical to the changes in the other bones of the body. ${ }^{24}$ A study was done in Japan to establish the risk factors that add to the development of the gum disease in the elderly. The study included 4542 subjects; citizens of the city of Niigata which were all older than 70 years. The results have shown that smoking and $6 \mathrm{~mm}$ critical level of periodontal attachment add to the gum disease in the older individual. ${ }^{25}$ The diseased gum deteriorates the mechanics of the teeth and results in the tooth loss. Experts from the University of Iowa have done a research on 65-year- 
old over the span of 13 to 15 years. They concluded that of 73 living subjects 45 of them lost all their teeth. The most frequent loss occurred in molar region in both jaws, while the most frequently persisting teeth were canine teeth and the maxillary incisors. The authors of the study attributed the tooth loss to the loss of periodontal attachment. ${ }^{26}$ Many studies show a connection between diabetes and periodontal disease. ${ }^{27} \mathrm{New}$ studies show that the percentage of people with diagnosed and undiagnosed diabetes is as high as $20 \%$ of the population ${ }^{28}$ and that $35 \%$ of adults between the ages of 30 and 90 suffer from gum disease. ${ }^{29}$ However, a study of 2003 in Canada showed a negligent connection between diabetes and gum disease. $^{30}$ There have been studies done to show a connection between depression in the older population and gum disease, caries and loss of teeth. Epidemiological studies done in the United States show that depression is the most diagnosed psychiatric illness of the aged. ${ }^{31}$ A group of Swedish scientists have also shown that people suffering from depression have a higher incidence of gum disease. The studies were done on the 298 citizens of the city of Jonkoping aged between 50 and 80 years. The results have confirmed the traumatic life experiences such as the loss of spouse add to the development of gum disease. ${ }^{32}$ A study in Denmark concluded that people living alone or have been alone for the last 7 years and are unhappy with their social life have a higher incidence of decay than the people who live with a partner and are happy with their social interaction. ${ }^{33}$ Persson et al also studied the issue and came to conclusion that depression is not connected to the higher risk of gum disease, but is connected to the tooth loss and chronic diseases. ${ }^{34}$ Old age chronic illnesses contribute to the deterioration of oral mucosa, as well as the local irritations due to inadequate prosthodontic appliances, tend to develop oral problems. The oral mucosa in the elderly is different compared with that of younger individuals, due to processes such as development of the epithelium thinning, lower cellular proliferation, loss of submucosal elastine and fat, as well as the increase in the fiber of connecting tissue and degeneration of the collagen. Visible clinical manifestations of this condition are an atrophy of the oral mucosa, loss of the elasticity and movement, resulting in the tissue changes that lead to traumas and infections. Oral mucosa provides an anatomical barrier whose vulnerability increases with age. The oral mucosa suffers the similar changes to the skin, as studied by MacEntee et al. ${ }^{35}$ The purpose of the study done in Istanbul was to determine the degree of mouth hygiene, the cleanliness of dentures and the presence of yeast infections and stomatitis in the elderly population. The results of the study showed that $55.7 \%$ had symptoms of stomatitis, of which $44 \%$ had local, diffuse or granular character. The Candida albicans infection was found in $38.6 \%$ of the subjects. The poor denture hygiene was the case in $48.6 \%$, while $15.7 \%$ of the examinees had excellent denture hygiene. ${ }^{36}$ Axelsson and Lindhe studied the oral hygiene in the elderly and the handicapped patients, and in 1987 they proved that chlorhexidine spray was an easy method in the chemical plaque control. ${ }^{37}$ In 2003, aim of the study made on 13 clients of the Grenadian home for the aged, was to determine an effect of the daily to twice daily usage of the $0.2 \%$ chlorhexidine spray. The results showed that there was no difference in the daily and twice daily usage of the spray. ${ }^{38}$ Due to the changes in the periodontal tissue and the receding gums, the roots are exposed with or without presence of the tooth decay. Bacterially rich exposed cervical tooth area becomes prone to tooth decay due to a deposit of plaque and calculus. Also there is a shrinking of the endodontic space, more frequent in males and patients suffering of arthritis, gallbladder and kidney stones, arteriosclerosis and hypertension. ${ }^{39}$ The older people in many cases suffer from hard and soft dental tissues illnesses of different etiology that can contribute to the necrotic changes of the pulp and the loss of tooth vitality. The therapy prescribed in these cases is tooth extraction or endodontic treatment which is usually not a common decision because of root canal obliterations, as well there is an opinion that such treatment on distal teeth in older patients is not worth the effort. Therapies that involve planning are essential in keeping the teeth that will play a crucial role in retention of removable partial dentures and preservation of alveolar bone. An infection of the root canal in healthy older patients will not diminish the success of the endodontic therapy. ${ }^{40}$ The Swedish study showed that aging combined with different factors such as lowered salivation, presence of lactobacillus and Streptococcus mutans, number of teeth, number of smoked cigarettes daily, oral hygiene and the combination of prescribed medication increases risk toward tooth decay. ${ }^{41}$

\section{CONCLUSION}

Aging of the individual is manifested at all levels of the organization hierarchy, from the macromolecular to that of the population. Although death is the unequivocal end result of the aging processes, an important consequence for health care delivery is the increased incidence of impairment, disability and handicap in the aging population. There are specific consequences to the aging of the stomatognathic system. The aging, first of all, brings changes in the oral mucosa and the salivary glands, lowered elasticity of the periodontal tissues resulting in the biomechanical problems of the teeth. To these conditions, one can add the decrease in a number of teeth crucial in the chewing process and breakdown of food into smaller pieces to aid digestion and the transference of nutrients throughout the body. The population studies referred a larger number of subjects of all age groups over 65 years with different access to medical and dental care, standard of living of the individual and the country the individual lives in. There will be an increase in the number of aged patients with dental problems; hence, many of the studies done today consider the different factors affecting the medical and dental health of this particular group within the overall population. Structured and methodical analyses of the problems are necessary to enable effective, preventative and therapeutic medical and dental care of the older population. 


\section{REFERENCES}

1. Duraković Z et al. Medicina starije dobi. Zagreb; Naprijed, 1990.

2. Ćatović A. Gerontostomatologija. Zagreb; Medicinska naklada, 2010.

3. WHO. International classification of functioning, disability and health (21st ed) 2001. Geneva: Resolution WHA P. 54.

4. Buchner D, Wagner E. Preventing frail health. Clin Geriatr Med 1992;8:1-17.

5. Mersel A, Peretz B. A behavioural approach in the treatment of elderly patients: A new philosophy. Int Dent J 2003;53:51-56.

6. Douglas CW, Shih A, Ostry L. Will there be a need for complete dentures in the United States in 2020? J Prosthet Dent 2002;87: 5-8.

7. Douglas CW, Watson AJ. Future needs for fixed and removable partial dentures in the United States. J Prosthet Dent 2002; 87:9-14

8. Heinrich-Weltzien R, Kunzel W, Borutta A, Lenz E, Ficher R, Silla M, Vrbič V. Edentulism and dental status in older populations of eight European countries. Acta Stomatol Croat 1997;189-99.

9. Mack F, Mojon P, Budtz-Jorgensen E, Kocher T, Splieth C, Schwahn C, et al. Caries and periodontal disease of the elderly in Pomerania, Germany: Results of the Study of Health in Pomerania. Gerodontology 2004;21:27-36.

10. Marcus PA, Joshi A, Jones JA, Morgano SM. Complete edentulism and denture use for elders in New England. J Prosthet Dent 1996;76:260-66.

11. Petersen PE, Kjoller M, Boge Christensen L, Krustrup U. Changing dentate status of adults, use of dental health services and achievement of National Dental Health Goals in Denmark by the year 2000. J Public Health Dent 2004;64(3):127-35.

12. Bailit HL, Braun R, Maryniuk GA, Camp P. Is periodontal disease the primary cause of tooth extraction in adults? J Am Dent Assoc 1987; 114:40-45.

13. Chauncey HH, Glass RL, Alman JE. Dental caries. Principal cause of tooth extraction in a sample of US male adults. Caries Res 1989;23:1200-05.

14. Krall EA, Wehler C, Garcia RI, Harris SS, Dawson-Huges B. Calcium and vitamin D supplements reduce tooth loss in the elderly. Am J Med 2001;111:452-56.

15. Morse DE, Holm-Pedersen P, Holm-Pedersen J, et al. Prosthetic crowns and other clinical risk indicators of caries among oldold Swedish adults: Findings from the KEOHS project. Kungsholmen elders oral health study. Gerodontology 2002;19:73-79.

16. Jones JA, Fedele DJ, Bolden AJ, Bloom B. Gains in dental care use not shared by minority elders. J Public Health Dent 1994;54:39-46.

17. Bergman $\mathrm{V}$, Ćatović $\mathrm{A}$, Ćatić $\mathrm{A}$, Bergman L. Istraživanje povezanosti stanja protetskih nadomjestaka, oštećenja organskih sustava i stupnja pokretljivosti štićenika doma umirovljenika. Acta Stomatol Croat 2005;85-90.

18. Ćatović A, Baučić I, Komar D. Stanje zubi i protetskih nadomjestaka u grupi gerijatrijskih pacijenata. Acta Stomatol Croat 1992;26:41-45.

19. Ćatović A, Jerolimov V, Ćatić A. Tooth loss and the condition of the prosthodontic appliances in a group of elderly home residents. J Oral Rehabil 2000;27:199-204.

20. Caloss R, Al-Arab M, Finn RA, Throckmorton GS. The effect of denture stability on bite force and muscular effort. J Oral Rehabil 2011;38(6): 434-39.

21. Hutton B, Feine J, Morais J. Is there an association between edentulism and nutritional state? J Can Dent Assoc 2002; 68(3):182-87.
22. Gunne HS, Wall AK. The effect of new complete dentures on mastication and dietary intake. Acta Odontol Scand 1985;43(5):257-68.

23. Shinkai RSA, Hatch JP, Rugh JD, Sakai S, Mobley CC, Saunders MJ. Dietary intake in edentulous subjects with good and poor quality complete dentures. J Prosthet Dent 1987;5:490-98.

24. Jorgić-Srdjak K. Stanje parodonta u starijih osoba in Ćatović A. Odabrana poglavlja iz gerontostomatologije, skripta. Stomatološki fakultet Sveučilišta u Zagrebu 2004.

25. Ogawa H, Yoshihara A, Hirotomi T, Ando Y, Miyazaki H. Risk factors for periodontal disease progression among elderly people. J Clin Periodontol 2002;29:592-97.

26. Warren JJ, Watkins CA, Cowen HJ, Hand JS, Levy SM, Kuthy RA. Tooth loss in the very old 13-15 year incidence among elderly Iowans. Community Dent Oral Epidemiol 2002;30: 29-37.

27. Grossi SG, Genco RJ. Periodontal disease and diabetes mellitus: A two way relationship. Ann Periodontol 1998;3:51-61.

28. Resnick HE, Shorr RI, Kuller L, Franse L, Harris TB. Prevalence and clinical implications of American Diabetes Association defined diabetes and other categories of glucose dysregulation in older adults. J Clin Epidemiol 2001;54:864-76.

29. Albandar JM, Brunelle JA, Kingman A. Destructive periodontal disease in adults 30 years of age and older in the United States. J Periodontol 1999;70:13-29.

30. Persson RE, Hollender LG, Macentee MI, Wyatt CCL, Kiyak HA, Persson GR. Assessment of periodontal conditions and systemic disease in older subjects. Focus on diabetes mellitus. J Clin Periodontol 2003;30:207-13.

31. Lyness JM, Bruce ML, Koenig HG, Parmelee PA, Schulz R, Lawton MP, Reynolds CF III. Depression and medical illness in late life. J American Geriatric Soc 1996;44:198-203.

32. Hugoson A, Ljungquist B, Breivik T. The relationship of some negative events and psychological factors to periodontal disease in an adult Swedish population 50-80 years of age. J Clin Periodontol 2002;29:247-53.

33. Avlund K, Holm-Pedersen P, Morse DE, Viitanen M, Winblad B. Social relations as determinants of oral health among persons over the age of 80 years. Community Dent Oral Epidemiol 2003;31:454-62.

34. Persson GR, Persson RE, Macentee CI, Wyatt CCJI, Hollender LG, Kiyak HA. Periodontitis and perceived risk for periodontitis in elders with evidence of depression. J Clin Periodontol 2003;30:691-96.

35. Macentee MI, Nolan A, Thomason JM. Oral mucosal and osseous disorders in frail elders. Gerodontology 2004;21:78-84.

36. Kulak-Ozkan Y, Kazazoglu E, Arikan A. Oral hygiene habits, denture cleanliness, presence of yeasts and stomatitis in elderly people. J Oral Rehabil 2002;29:300-04.

37. Axelsson P, Lindhe J. Efficacy of mouthrinses in inhibiting dental plaque and gingivitis in man. J Clin Periodontol 1987; 14:205-12.

38. Clavero J, Baca P, Junco P, Gonzalez P. Effects of $0.2 \%$ crorhexidine spray applied once or twice daily on plaque accumulation and gingival inflammation in a geriatric population. J Clin Periodontol 2003;30:773-77.

39. Šegović S, Šutalo J. Bolesti tvrdih zubnih tkiva u starijih osoba. in Ćatović A. Odabrana poglavlja iz gerontostomatologije, skripta. Stomatološki fakultet Sveučilišta u Zagrebu 2004.

40. Finbarr Allen P, Whitworth JM. Endodontic considerations in the elderly. Gerodontology 2004;21:185-94.

41. Fure S. Ten-year cross-sectional and incidence study of coronal and root caries and some related factors in elderly Swedish individuals. Gerodontology 2004;21:130-40. 